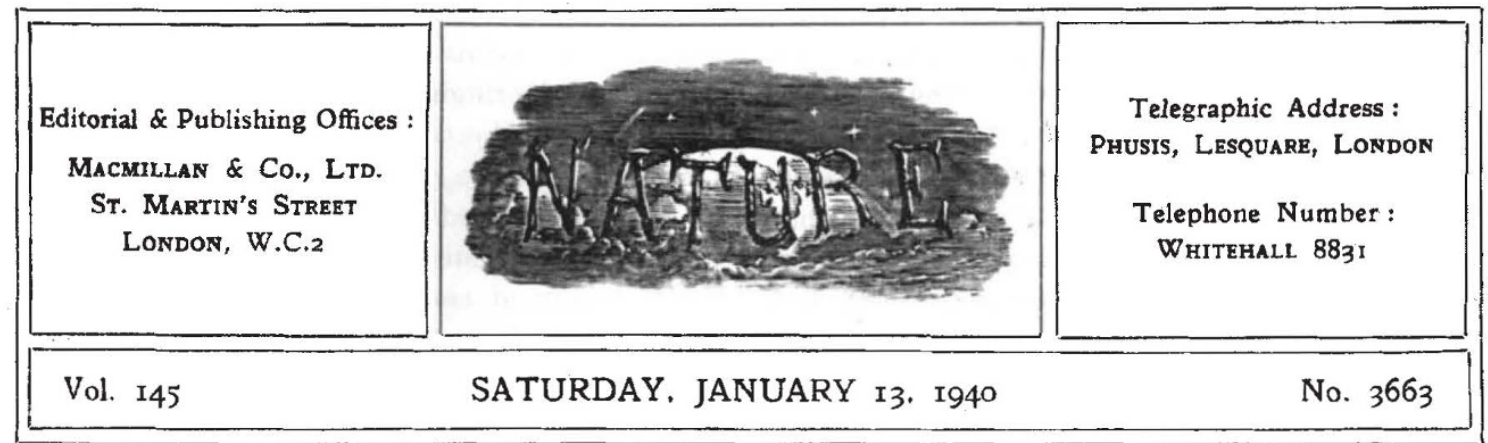

\title{
UTILIZATION OF SCIENTIFIC MAN-POWER
}

$\mathrm{T}^{\mathrm{T}}$ HE, concern which has recently found expression as to the position of science in the war effort of Great Britain, and the extent to which the services of scientific workers are being utilized, is evidence that the importance of this contribution is recognized far beyond the ranks of scientific workers themselves. The apparent tardiness with which the maximum contribution of science is being developed in the war-time effort of Great Britain has caused much questioning, and it is to be hoped that the activities of the newly appointed Advisory Council on Scientific Research and Technical Development will quickly overcome at least some of the obstacles which have appeared.

Political and Economic Planning (P E P) published a year ago an admirable broadsheet on "Man-Power Policy" in which four principles were laid down as essential and suggestions made for giving effect to them. It has now published a review of the present situation and its relation to economic policy under the title "Industrial ManPower", in which the effect of expansion and contraction in industry in war-time is considered. The table showing the changes which have occurred in certain industries between 1923 and 1938 in Great Britain and Northern Ireland suggests that the great 'dilution' problem of the War of 1914-18 may be of much less importance to-day, since there now exists a range of metal trades already staffed for munitions, without the need to create them afresh.

This factor particularly affects the position of women, and it is accordingly unlikely, in view of the work already carried out under the Industrial Health Research Board and the National Institute of Industrial Psychology, that the grave social problems arising out of physical difficulties through the industrial employment of women will recur. The chief reason for alarm indeed appears to lie in the tendency of the Government to dispense with the Factories Act. The recent report of the Industrial Health Research Board recalls that its work was born of the experience of the War of 1914-18, but there are signs that scientific workers must bestir themselves if that entirely new attitude towards the study of working conditions and industrial welfare is to be preserved under the stress of the present war.

In industry as in eivil defence, there is already evidence that the over-working of men and women has begun, and there are no signs of a consistent and well-understood policy in granting permission to work overtime. Equally it is important to conserve our limited resources of skilled labour by training, on a sufficient scale, fresh recruits for the less skilled operations. A scientific policy, which will keep alive the protective machinery and handle such problems before they become serious enough to damage health and efficiency, demands the co-operation of scientific workers as much as the prosecution of fresh research in these fields.

The difficulties experienced at the moment, how ever, are chiefly of a special and local character. There is some difficulty in spreading the available skilled workers evenly over the field, especially among the new munitions and aircraft factories. Social difficulties also attend the provision of the non-factory groups with work in munition factories. The dangers and opportunities in bringing many of these unorganized workers into official organizations are immense. Again, the labour requirements of several large industries, such as the textile groups, depend very much on policy, particularly export policy, and for this reason lack of a clear 
economic policy on the part of the Government is being held responsible for the rise in unemployment.

The PE P broadsheet forecasts a considerable scarcity of male labour in the coal-mining, shipbuilding and other heavy industries, rather than in the munitions industries, and stresses the fundamental changes in the whole structure of British society since the War of 1914-18 in relation to the industrial sources of man-power for the forces. A much greater proportion of the population is engaged in selling goods or performing personal services, and the entire non-factory working-class is larger in relation to the rest of the population. Of the non-factory groups, a much larger proportion are now employees rather than employers or workers on their own account. The distributive trades, personal services, and other nonfactory trades and occupations are regarded as important sources of personnel for the fighting services and civil defence.

The change in the framework of labour relations involves, for a thorough study of the man-power problem, a survey of the changes in organization, and the broadsheet comments on the great "civil service" which has grown up in industry, represented by thousands of paid officials, hundreds of joint committees and slow-moving democratic machinery. Smooth adaptation of labour relations to war problems as they arise will depend on whether such constitutions reveal latent elasticity or become too brittle to bear the strain.

The value of the National Register as a basis for the scientific use of man-power does not require stressing here. The P E P broadsheet refers particularly to the Central Register of scientific, technical, professional or higher administrative workers, which is already being used by Government Departments and by firms engaged on work of national importance. Much unemployment still exists, however, among highly trained technical workers, particularly graduates in chemistry and other sciences, and even among professional workers such as architects, whose services would be expected to be in demand in numerous problems involved in civil defence and evacuation. A special section of the Central Register has been formed of those in this position, but the preservation of their abilities would seem to require a considerable extension of research programmes, even if such activity has no immediate connexion with war. So far as chemists are concerned, the establishment by the Chemical Society of an Advisory Research Council already provides a means for pooling suggestions for research and bringing them before those engaged in research in the universities and colleges.

Something more is required than improvements in placing methods. Formulation of a really adequate programme of work and its adoption by the Government could scarcely fail to secure the efficient and adequate use of the available scientific personnel and the disappearance of unemployment from the scientific register.

Certain suggestions were made by Sir William Bragg in his presidential address at the anniversary meeting of the Royal Society (see Nature, Dec. 9, 1939 , p. 953). Sir William Bragg suggested that a Ministry of Science would be too formal and rigid for immediate needs and that personal and elastic methods of using knowledge were the most successful. We might well be content to bring science as a whole into close relation with government as a whole by attaching a central authority of science to the central authority of the country. The immediate application of science in any department of national affairs should be made from within that department, not from without, and the real need is for means of ensuring that the Government is able to rely on and make use of the whole range of scientific knowledge.

The value of the Royal Society as a consultative body, so strongly urged by Sir William Bragg, will be endorsed by all scientific workers, most of whom will agree that the Government could well utilize these services much more widely and fully. It is, however, the evidence of a bureaucratic outlook, indicated by the interruption of important research as a result of evacuation or other exigencies and the neglect to provide alternative accommodation, that has occasioned misgivings in the minds of scientific workers. The Advisory Research Council of the Chemical Society appears to be the first organized attempt to mobilize the research resources of the country at the universities or elsewhere, and it may be hoped that the new Advisory Council will extend the process quickly and effectively.

In the meantime scientific workers might well follow the lead of Prof. J. D. Bernal, who at the recent annual council meeting of the Association of Scientific Workers alluded to a number of scientific problems which would appear to have been overlooked in the present situation. Suggestions for investigation should not be restricted to any one field. Prof. Bernal himself referred to 
the need for a seientific study of 'black-out' psychology and the effects of the 'black-out' on the temperament of the community. Similarly, problems of health and hygiene raised by evacuation and other changes await investigation.

Besides the suggestion and initiation of lines of investigation, the maximum development of our scientific effort in war demands an immense educational effort, and whatever central body is established will require to have under careful consideration the propaganda of science. Science cannot be used to the best advantage without the eo-operation of the whole public. The stimulation of public interest in science is of vital importance to public efficiency and technical morale, and incidentally should provide a check on the bureau- cratic tendencies which have been causing concern in some quarters.

The educational aspect is of importance from another point of view also. There is perhaps the danger that in the mobilization of scientific effort and resources in support of our cause, there may be further disposition to blame science for some of the evils of war. Propaganda of the type we have indicated should do more than prevent such misunderstanding. By promoting that full understanding and sympathy which are essential in the highest technical achievements, they should also prepare the way for science to make its full contribution, undisturbed by the demands of war, to the advancement of knowledge and the enrichment of human living.

\section{VICTORIAN SOCIALISM}

\section{The New World Order}

Whether it is Attainable, How it can be Attained, and What Sort of World a World at Peace will have to be. By H. G. Wells. Pp. 192. (London : Martin Secker and Warburg, Ltd., 1940.) 6s. net.

"FEW human beings," says Mr. Wells in his new book, "are able to change their primary ideas after the middle thirties. They get fixed in them and drive before them no more intelligently than animals before their innate impulses." Here he does himself a great injustice. We used to wonder what panacea he would discover next. $\mathrm{He}$ was sure to advocate it in a brilliant and stimulating manner.

But the time comes to all of us--it came to me long ago--when our minds stiffen, and we become, as a Frenchman unkindly said, the comedians of our early convictions. The hardships of his early life have permanently embittered Mr. Wells against the class in which his genius has placed him. He sees Red when he thinks of them, and exults in the destitution which he hopes awaits them.

So, since he is far too well-informed to be a Bolshevik, he has nailed his colours to that waterlogged derelict, Fabian collectivism. We have only to make a clean sweep of emulation, ambition, love of private ownership, patriotism and pugnacity, and we shall all be as happy, progressive and intelligent as a flock of sheep. That is always the way with Utopians. Abolish all the strongest passions and instincts of human nature, and a terminal state of blessedness, an earthly paradise, will be reached.
It is pathetic to look at the row of deserted idols which we used to worship in the last century : Liberalism, Democracy, Human Perfectibility, Socialism, Communism - there are few any more to do them reverence. Liberalism, which might sweep the suburbs with the Gladstonian creed of peace and retrenchment, is content to limp feebly after Labour, and has paid the penalty. Democracy is still a fetish in America, where it means anything, from an attribute of the Deity to a method of therapeutics, except what it really is, a not very successful experiment in government. "Uric acid," I read in a New York medical journal, "is tottering on its throne. The triumphs of Democracy are not confined to politics." Elsewhere it is merely accepted from inertia, or from fear of something worse. No institution has lost in prestige so much as the House of Commons. Who now reads the dreary debates, which are not expected to turn a single vote? (Democracy as a form of society-equality of consideration-is a different matter; some other name ought to be found for it.) As for human perfectibility, nobody any longer believes in a law of progress. The fact of progress in the past-for example, in the eighteenth and nineteenth centuries - cannot be denied. But in the future? We began with faith, we went on with hope; now there is nothing left but charity.

Socialism has never recovered from giving birth to its misbegotten brat Communism. There was such a thing as Social Democracy, though Socialism and Democracy are fundamentally incompatible. Nothing could be more ignominious than the total collapse of the Social Democrats in Italy and 